\title{
PEMANFAATAN MEDIA SOSIAL DALAM PEMASARAN PRODUK UMKM DI KELURAHAN SIDOKUMPUL, KABUPATEN GRESIK
}

\author{
Zainal Abidin Achmad, ${ }^{1}$ Thareq Zendo Azhari ${ }^{2}$, Wildan Naufal Esfandiar ${ }^{3}$, Nafila \\ Nuryaningrum $^{4}$, Anisah Farah Dhilah Syifana ${ }^{5}$, Indah Cahyaningrum ${ }^{6}$ \\ ${ }^{1-6}$ Universitas Pembangunan Nasional "Veteran" Jawa Timur \\ E-mail: z.abidinachmad@upnjatim.ac.id
}

\begin{tabular}{l}
\hline Article Info \\
\hline Article history: \\
Received 1 Maret 2020 \\
Accepted 20 Maret 2020 \\
Published 10 April 2020 \\
\hline
\end{tabular}

Keyword:

Pemasaran Digital, Sosial

Media, UMKM

Sidokumpul Gresik

\begin{abstract}
This research discusses how the use of social media in marketing UMKM products in Sidokumpul Village, Gresik District, Gresik Regency. The research objective is to introduce UMKM products to the wider community in order to get a bigger market potential. This research method is qualitative by using phenomenological approach. The research result is, the use of social media provides good prospects for increasing the sales of UMKM products in Sidokumpul Village, Gresik District, Gresik Regency which is experiencing the impact of the COVID-19 pandemic. This is because the digital marketing system provides an online buying and selling platform, in order to facilitate the ordering and purchasing process. So that buyers can interact with UMKM owners to make transactions directly.
\end{abstract}

Penelitian ini membahas tentang bagaimana pemanfaatan media sosial dalam pemasaran produk UMKM di Kelurahan Sidokumpul, Kecamatan Gresik, Kabupaten Gresik. Tujuan penelitian adalah untuk mengenalkan produk-produk UMKM kepada masyarakat luas agar mendapatkan potensi pasar yang lebih besar. Metode penelitian ini adalah kualitatif dengan menggunakan pendektaan fenomenologi. Hasil penelitian adalah, pemanfaatan media sosial memberikan prospek yang baik untuk menaikkan angka penjualan produk UMKM di Kelurahan Sidokumpul, Kecamatan Gresik, Kabupaten Gresik yang mengalami dampak pandemi COVID19. Hal itu disebabkan karena sistem pemasaran digital menyediakan platform jual beli secara daring, agar memudahkan proses pemesanan dan pembelian. Sehingga pembeli dapat berinteraksi dengan pemilik UMKM untuk melakukan transaksi secara langsung.

\section{Editorial Office:}

Program Studi Ilmu Komunikasi, Fakultas Dakwah dan Komunikasi, UIN Sunan Ampel Surabaya. Jl. Ahmad Yani 117 Surabaya, Jawa Timur, Indonesia.

Email: jurnalilkom@uinsby.ac.id 


\section{Pendahuluan}

Pandemi COVID-19 memiliki dampak besar terhadap segala aspek dan sektor di kehidupan masyarakat terutama pada sektor ekonomi. Menteri Keuangan Sri Mulyani mengatakan ada 3 dampak besar ekonomi pada pandemi COVID-19. Pertama, berdampak pada konsumsi rumah tangga atau daya beli masyarakat yang jatuh. Kedua, investasi ikut melemah ditengah ketidakpastian pandemi COVID19. Dan ketiga, pelemahan ekonomi seluruh dunia yang membuat ekspor Indonesia terhenti. ${ }^{1} \quad$ Dikarenakan menurunnya kegiatan masyarakat di luar rumah, maka secara otomatis juga menimbulkan penurunan jumlah pembeli pada suatu usaha. Sehingga pendapatan yang diperoleh menjadi berkurang. Dampak tersebut tidak hanya dirasakan oleh industri besar, pandemi virus Corona juga memberikan dampak terhadap pelaku Usaha Mikro, Kecil, dan Menengah (UMKM) di Indonesia.

Dampak COVID-19 terhadap pelaku UMKM juga dialami oleh warga Kelurahan Sidokumpul, Kecamatan Gresik, Kabupaten Gresik, Jawa Timur yang menjadi pelaku UMKM. Ada sekitar 11 UMKM yang dimiliki oleh warga setempat. Terdiri atas kuliner, jasa jahit dan toko sembako. Menurut survey yang telah kami lakukan, semua pelaku UMKM di Kelurahan Sidokumpul mendapatkan dampak yang cukup besar dari pandemi COVID-19 ini, dari mulai suami yang

\footnotetext{
${ }^{1}$ Anggun P. Situmorang, Sri Mulyani: Corona Beri 3 Dampak Besar Ekonomi Indonesia, Liputan6.com, Juni 30, 2020, https://m.liputan6.com/bisnis/read/4292763/srimulyani-corona-beri-3-dampak-besar-ke-ekonomiindonesia.
}

kehilangan pekerjaan karena adanya PHK sampai menurunnya jumlah pembeli.

Di zaman sekarang dengan perkembangan teknologi dan komunikasi yang semakin canggih, pemilihan penggunaan pemasaran melalui media sosial menjadi pilihan utama yang dilakukan oleh pelaku usaha, sekarang ini penggunaan media sosial telah menjadi pilar utama dalam penyampaian informasi. Salah satu kelebihan media sosial adalah memiliki banyak potensi untuk kemajuan suatu usaha. Media sosial dapat digunakan untuk melakukan komunikasi dalam bisnis, membantu pemasaran produk dan jasa, berkomunikasi dengan pelanggan dan pemasok, melengkapi merk, mengurangi biaya dan untuk penjualan online. ${ }^{2}$

Pada era digital, media sosial saat ini telah menjadi trend dalam komunikasi pemasaran. Media sosial adalah sebuah media online, dengan para penggunanya bisa dengan mudah berpartisipasi, berbagi, dan menciptakan isi meliputi blog, jejaring sosial, wiki, forum dan dunia virtual. Blog, jejaring sosial, dan wiki merupakan bentuk media sosial yang paling umum digunakan oleh masyarakat di seluruh dunia.

Ada beberapa media sosial yang sedang booming saat ini antara lain Whatsapp, Instragam, Twitter, Line, Telegram, Facebook, Youtube, dan lainlain. Seseorang pasti memiliki berbagai motivasi dalam menggunakan media sosial. Sekedar untuk berkomunikasi dengan orang lain, untuk mencari tahu perkembangan sesuatu, untuk berbagi

\footnotetext{
${ }^{2}$ Zainal Abidin Achmad dan Setiyanti, O. W. The Effectiveness of Use of Soundcloud Application for Promoting Pop Punk Songs and Music. Bali International Seminar on Science and Technology, Desember 7, 2012. www.engadget.com/2012/12/07/editorial-
} 
informasi maupun untuk mengikuti salah satu yang menjadi trend saat ini yaitu menggunakan media sosial sebagai bentuk eksistensi diri. Bagi orang-orang yang ingin diakui eksistensinya oleh masyarakat luas melalui media sosial biasanya akan menggunakan media sosial yang bersifat terbuka seperti Instagram, Facebook, Line, atau Twitter. ${ }^{3}$ Karena melalui media social disinilah tempat kita bisa secara bebas dan terbuka dalam berinteraksi. Sehingga banyaknya update status serta postingan yang kita miliki adalah salah satu bentuk jika kita ingin dikenal secara luas.

Media sosial juga dapat mempunyai tujuh fungsi potensial dalam bisnis yaitu mengidentifikasi pelanggannya, mengadakan komunikasi timbal balik, membagikan informasi untuk dapat mengetahui obyek yang disukai pelanggan, kehadiran pelanggan, hubungan antar pelanggan berdasarkan lokasi dan pola interaksi, reputasi perusahaan di mata pelanggan dan membentuk kelompok antar pelanggan. Distribusi yang didukung oleh teknologi pun mampu meningkatkan kuantitas produk untuk sampai ke tangan konsumen.

Media sosial yang saat ini menjadi tren anak-anak muda mengekspresikan diri menjadi peluang besar sebagai media iklan maupun promosi bisnis. Media sosial seperti Facebook, Instagram, Twitter, WhatsApp, dan lain sebagainya sekarang banyak dimanfaatkan untuk media bisnis, baik dari produk produk yang sudah

\footnotetext{
${ }^{3}$ Zainal Abidin Achmad, Integrasi Program Dakwah dan Budaya: Studi Etnografi Virtual Mediamorfosis Radio Nada FM Sumenep Madura, Jurnal Komunikasi Islam 09 no. 2 (Desember 2019): 245, https://doi.org/10.15642/jki.2019.9.2.239-263.

${ }^{4}$ Tutiasri, et al., Creative Marketing Strategies of Sembung Batik. Proceedings of the 2nd
}

ternama hingga produk buatan sendiri. Dengan internet para pelaku usaha dapat memberikan efisiensi anggaran pemasaran, internet memiliki jangkauan yang luas, akses mudah dan biaya murah. Hal ini terbukti dengan banyaknya usaha yang mencoba menawarkan berbagai macam produk menggunakan media sosial. ${ }^{4}$

Media sosial memang sangat diminati UMKM untuk mengembangan bisnisnya. Media sosial mempunyai pengaruh yang sangat besar, masyarakat lebih cepat menerima informasi lewat internet. Dengan akses yang mudah dan cepat hal ini dimanfaatkan oleh para pengusaha kecil UMKM untuk lebih berani mempromosikan produk produknya karena jaringan internet sangat luas dan tidak ada batasan waktu dan wilayah hingga menjadikan media pemasaran yang efektif. $^{5}$

Saat pandemi COVID-19 terjadi dan masih berlangsung, jumlah tersebut akan terus meningkat seiring dengan adanya kebijakan jaga jarak fisik yang membuat masyarakat melakukan kegiatannya sacara daring. Oleh karena itu media sosial dapat dijadikan sebagai alat untuk mengembangkan dan mengoptimalkan usaha terutama usaha mikro kecil menengah (UMKM) khususnya untuk mempromosikan usaha-usahanya.

Dengan adanya pengenalan sistem pemasaran digital ini diharapkan para pelaku UMKM Kelurahan Sidokumpul bisa lebih mengoptimalkan dan

International Media Conference 2019 (IMC 2019), (March, 2020), https://doi.org/10.2991/assehr.k.200325.030

5 Arum Wahyuni Purbohastuti "Efektivitas Media Sosial Sebagai Media Promosi”. Jurnal Tirtayasa EKONOMIKA, 12, no. 2 (Oktober 2017): 230. http://jurnal.untirta.ac.id > article > download 
meningkatkan pengetahuan mengenai sistem pemasaran digital atau sistem pemasaran online, sebab melalui sistem pemasaran digital atau sistem pemasaran online produk-produk dari UMKM akan dapat lebih dikenal oleh masyarakat, pemesanan bisa dilakukan secara online, sehingga dapat memudahkan pembeli dan pelaku UMKM dalam bertransaksi jual beli ditengah pandemi COVID-19 saat ini. ${ }^{6}$

Selain itu, era globalisasi sekarang ini juga dikenal sebagai Era Ekonomi Baru (New Economy Era), Era Ekonomi Digital (Digital Economy Era). Era Ekonomi baru ditandai dengan penerapan teknologi informasi di dalam menjalankan kegiatan ekonominya. ${ }^{7}$ Penerapan teknologi informasi yang dibutuhkan yaitu dengan model pemasaran produk umkm melalui media sosial facebook dan instargram untuk Usaha Mikro, Kecil, dan Menengah. Pengenalan dan penyuluhan sistem pemasaran digital atau sistem pemasaran online ini dianggap lebih praktis, mudah dan cepat dibanding dengan sistem pemasaran digital manual hanya saja memang sistem pemasaran digital atau pemasaran online ada dampak positif dan negatifnya. ${ }^{8}$

Pemanfaatan media sosial memang dapat memberikan kemudahan dalam proses promosi dan jual beli yang dilakukan oleh para UMKM untuk memasarkan produknya serta dapat

6 Helmalia dan Afrinawati, “ Pengaruh ECommerce Terhadap Peningkatan Usaha Mikro Kecil Dan Menengah Di Kota Padang" Jurnal Ekonomi Dan Bisnis Islam 3 no 2 (Juli 2018): 240, doi: http://dx.doi.org/10.15548/jebi.v3i2.182

7 Ertien Rining Nawangsari dan Arimurti Kriswibowo, ed., Potret Masyarakat dan Kebijakan Pemerintah dalam Menghadapi Tantangan Pandemi COVID-19, (Surabaya: Program Studi meminimalkan biaya. Namun masih banyak pula pelaku UMKM yang kurang mengerti dengan pemanfaatan media sosial untuk memasarkan bisnisnya, mereka masih melakukan pemasaran secara tradisional yaitu dengan memasarkan produk langsung kepada konsumen yang hanya mempunyai cakupan wilayah yang masih kecil. Biasanya adalah pelaku usaha dikalangan orang tua yang belum mengetahui tentang pemasaran online. Atas latar belakang tersebut, KKN UPN Veteran Jawa Timur Kelompok 45, divisi pemberdayaan wirausaha/umkm yang sedang melakukan KKN di Kelurahan Sidokumpul, Kecamatan Gresik, Kabupaten Gresik menggunakan latar belakang tersebut sebagai program kerja divisi UMKM.

\section{Kajian Pustaka}

Definisi UMKM menurut UndangUndang No. 20 Tahun 2008 tentang Usaha Mikro, Kecil dan Menengah (UMKM) penyebutkan definisi UMKM adalah sebagai berikut: Usaha Mikro adalah usaha produktif milik orang perorangan dan/atau badan usaha perorangan yang memenuhi kriteria Usaha Mikro sebagaimana diatur dalam Undang-Undang ini. Usaha Kecil adalah usaha ekonomi produktif yang berdiri sendiri, yang dilakukan oleh orang perorangan atau badan usaha yang bukan merupakan anak perusahaan atau bukan

Ilmu Administrasi Negara, UPN 'Veteran' Jawa Timur, 2020), 19

8 Nur Ira dkk., "Workshop Pemasaran Online Mahasiswa KKN-PPM Universitas PGRI Adi Buana Surabaya Desa Bulang Prambon Sidoarjo", (Surabaya: Abadimas Adi Buana, 2017), 19. 
cabang perusahaan yang dimiliki, dikuasai, atau menjadi bagian baik langsung maupun tidak langsung dari Usaha Menengah atau Usaha Besar yang memenuhi kriteria Usaha Kecil sebagaimana dimaksud dalam Undang-Undang ini.

Usaha Menengah adalah usaha ekonomi produktif yang berdiri sendiri, yang dilakukan oleh orang perorangan atau badan usaha yang bukan merupakan anak perusahaan atau cabang perusahaan yang dimiliki, dikuasai, atau menjadi bagian baik langsung maupun tidak langsung dengan Usaha Kecil atau Usaha Besar dengan jumlah kekayaan bersih atau hasil penjualan tahunan sebagaimana diatur dalam Undang-Undang ini.

Berdasarkan UU No 20 tahun 2008 di atas jelas menunjukan perbedaan yang cukup besar baik dari segi asset ataupun omzet antara usaha mikro dengan kecil dan usaha kecil dengan menengah. Namun yang jelas secara keseluruhan UMKM berperan dalam pembangunan perekonomian nasional, hal ini sesuai juga dengan UU No 20 Tahun 2008 Bab II pasal yang berbunyi: "usaha mikro kecil dan menengah bertujuan menumbuhkan dan mengembangkan usahanya dalam rangka membangun perekonomian nasional berdasarkan demokrasi ekonomi yang berkeadilan."

Kriteria Usaha Mikro adalah sebagai berikut: Memiliki kekayaan bersih paling banyak Rp50.000.000,00 (lima puluh juta rupiah) tidak termasuk tanah dan bangunan tempat usaha; atau Memiliki hasil penjualan tahunan paling banyak Rp300.000.000,00 (tiga ratus juta rupiah).

Kriteria Usaha Kecil adalah sebagai berikut: Memiliki kekayaan bersih lebih dari Rp50.000.000,00 (lima puluh juta rupiah) sampai dengan paling banyak Rp500.000.000,00 (lima ratus juta rupiah) tidak termasuk tanah dan bangunan tempat usaha; atau Memiliki hasil penjualan tahunan lebih dari Rp 300.000.000,00 (tiga ratus juta rupiah) sampai dengan paling banyak Rp 2.500.000.000,00 (dua milyar lima ratus juta rupiah).

Kriteria Usaha Menengah adalah sebagai berikut: Memiliki kekayaan bersih lebih dari Rp500.000.000,00 (lima ratus juta rupiah) sampai dengan paling banyak Rp10.000.000.000,00 (sepuluh milyar rupiah) tidak termasuk tanah dan bangunan tempat usaha; atau Memiliki hasil penjualan tahunan lebih dari Rp2.500.000.000,00 (dua milyar lima ratus juta rupiah) sampai dengan paling banyak Rp50.000.000.000,00 (lima puluh milyar rupiah).

Situs yang menjadi wadah untuk memudahkan semua orang berkomunikasi, berpartisipasi, saling bertukar informasi, dan membentuk sebuah jaringan online dengan teman-teman dan kerabat mereka, baik yang mereka kenal di dunia nyata maupun dunia maya dapat disebut dengan media jejaring sosial. Dalam artikelnya di Horizons Bisnis yang terbit tahun 2010, Kaplan dan Haenlein mengklasifikasikan jenis media sosial menjadi 6 yaitu: proyek kolaborasi (contohnya wikipedia), blog dan microblogs (contohya twitter), komunitas konten (contonhnya youtube), situs jaringan sosial (contohnya facebook, instagram), virtual game (contohnya world 
of warcraft), dan virtual social (contohnya second life). ${ }^{9}$

Usaha Elektronik Commerce (ECommerce) atau lebih dikenal sebutan Online Shopping adalah pelaksanaan perniagaan berupa transaksi penjualan, pembelian, pemesanan, pembayaran, maupun promosi suatu produk barang dan/atau jasa dilakukan dengan memanfaatkan komputer dan sarana komunikasi elektronik digital atau telekomunikasi data. ${ }^{10}$ Selain itu, bentuk perniagaan ini juga dapat dilakukan secara global, yaitu dengan menggunakan jaringan internet. ${ }^{11}$

Kotler menyatakan layanan online menjadi populer bagi pelanggan karena: (1) Kemudahan Pelanggan dapat memesan produk 24 jam. Mereka tidak harus berkendara, mencari tempat parkir, melewati gang yang panjang untuk mencari barang. Mereka tidak harus berkendara ke toko, hanya untuk menemukan barang yang dicari sudah habis, (2) Informasi Pelanggan memperoleh informasi tentang perusahaan, produk, dan pesaing tanpa meninggalkan kantor atau rumah mereka. Sehingga dapat lebih selektif dalam hal harga, kualitas, kinerja, dan ketersediaan. (3)Rongrongan yang lebih sedikit Pelanggan tidak perlu menghadapi atau melayani bujukan.

\footnotetext{
${ }^{9}$ Andres Kaplan \& Michael Haenlein, User Of The World, Unite! The Challenges and Opportunities of Social Media, Business Horizons 53 (Februari, 2010): 63, DOI: 10.1016/j.bushor.2009.09.003

10 Arif Ardiyanto, Analisis Penggunaan Media Sosial dalam Pengembangan Usaha Mikro, Kecil, dan Menengah (UMKM) di Desa Kemasan Kecamatan Sawit Kabupaten Boyolali, Skripsi, (Surakarta: Fakultas Ekonomi dan Bisnis Islam, Manajemen Bisnis Syariah, Institut Agama Islam Negeri Surakarta, 2018): 10.

11 Okto Aditya Suryawirawan, Perceived Ease of Usedan Perceived Usefulnessterhadap E-
}

Sedangkan bagi pemasar, layanan Online memiliki manfaat: (1)Penyesuaian yang cepat terhadap kondisi pasar Perusahaan dapat dengan cepat menambahkan produk pada penawaran serta mengubah harga (2) Biaya yang lebih rendah Mencegah biaya pengelolaan toko, biaya sewa, asuransi, dan prasarana. Membuat katalog digital dengan biaya yang lebih murah. (3) Peningkatan hubungan, karena pemasar online dapat berbicara dengan pelanggan dan belajar banyak dari mereka. (4) Pengukuran besar peminat pasar, karena pemasar mengetahui berapa banyak orang yang mengunjungi situs online mereka. Informasi ini dapat membantu pemasar meningkatkan penawaran dan iklan mereka. ${ }^{12}$

Beberapa manfaat pemasaran Online antara lain: murah dan efisien, tidak terbatas oleh waktu, menjangkau pasar lebih luas, meningkatkan image perusahaan dimata para konsumen, memberikan nilai lebih untuk menghadapi persaingan bisnis yang ada, mengurangi biaya pemasaran, lebih tertarget dan biayanya relatif lebih rendah dibandingkan biaya pemasaran offline, memudahkan pelaku usaha untuk menjalin hubungan dengan para konsumen melalui kotak saran atau ruang komentar, meningkatkan loyalitas konsumen. ${ }^{13}$

Commerce Intentionmelalui Aplikasi Online Shoppada Mahasiswa Di Surabaya, Jurnal MEBIS 4 no 1, (July, 2019): 3, https://doi.org/10.33005/mebis.v4i1.46

12 Enjat Munajat dkk. Analisis Penggunaan Media Sosial untuk Mendukung Pemasaran Produk UMKM (Studi Kasus Kabupaten Subang, Jawa Barat), Jurnal Pengabdian Kepada Masyarakat 2 no 10 (Oktober, 2018): 897 , http://jurnal.unpad.ac.id/pkm/article/view/20445

13 Yunita Purnamasari, Ari Pradhanawati, Wahyu Hidayat, " Analisis peluang E-Commerce Dalam Pengembangan Usaha Mikro Dan Menengah 
Penjualan adalah usaha yang dilakukan manusia untuk menyampaikan barang bagi mereka yang memerlukan dengan imbalan uang menurut harga yang telah ditentukan secara elektronik. Tujuan umum penjualan yaitu : 1. Mencapai volume penjualan; 2. Mendapatkan laba tertentu; dan 3. Menunjang pertumbuhan usaha. ${ }^{14}$

\section{Metode Penelitian}

Penelitian kualitatif deskriptif ini menggunakan pendekatan fenomenologi. Metode fenomenologis berusaha memahami arti peristiwa dan kaitannya terhadap orang-orang yang berada dalam situasi tertentu. Metode fenomenologis menekankan pada pengalaman subyektif atau pengalaman fenomenologikal. ${ }^{15}$ Peneliti bertujuan untuk mengeksplor fenomena yang bersifat deskriptif dengan melakukan pengamatan, pemahaman dan penghimpunan data, penganalisisan dan pembuatan kesimpulan terhadap suatu fenomena. Pendekatan penelitian deskriptif kualitatif merupakan salah satu dari jenis penelitian yang menyampaikan gambaran penuh mengenai keadaan sosial atau hubungan antara fenomena yang diteliti. $^{16}$ Metode kualitatif diharapkan mampu meghasilkan suatu uraian mendalam tentang ucapan, tulisan, dan

Produk Batik" (Studi Kasus pada Usaha Batik di Semarang), Jurnal Ilmu Administrasi Bisnis 4 no. 4 (September, 2015): 45, https://ejournal3.undip.ac.id/index.php/jiab/article/ view/9226

14 Basu Swastha Dharmmesta, Manajemen Penjualan. cetakan kelima, (Yogyakarta: Penerbit BFSE, 2001), 32.

15 Izzati Baril Haq, Henna Sebagai Komunikasi Identitas Budaya (Studi Fenomenologi Pemahaman \& Pemaknaan Laki-Laki Pengguna Henna Di Kampung Arab Surabaya), Jurnal Voxpop, 1no. 1 (September, tingkah laku yang dapat diamati dari suatu individu, kelompok, masyarakat, organisasi tertentu dalam suatu konteks setting tertentu yang dikaji dari sudut pandang yang utuh, komprehensif dan holistic. ${ }^{17}$ Penelitian ini mengamati dan mendeskripsikan mengenai pemahaman penggunaan media sosial pada pengembangan UMKM pada usaha yang ada di Kelurahan Sidokumpul.

Data yang diperoleh akan dianalisis secara kualitatif yaitu analisis yang dilakukan dengan memahami dan merangkai data yang telah dikumpulkan dan disusun secara sistematis, kemudian ditarik kesimpulan. Dalam penelitian kualitatif, kesimpulan yang dihasilkan pada umumnya tidak dimaksudkan sebagai generalisasi, tetapi sebagai gambaran interpretatif tentang realitas atau gejala yang diteliti secara holistik dalam setting tertentu. ${ }^{18}$ Di sini, dikandung arti bahwa temuan apapun yang dihasilkan pada dasarnya bersifat terbatas pada kasus yang diamati. Oleh karena itu, prinsip berfikir induktif lebih menonjol dalam penarikan kesimpulan dalam penelitian komunikasi kualitatif. Teknik pengumpulan data menggunakan penyebaran kuisioner dan wawancara secara langsung kepada sebelas

http://voxpop.upnjatim.ac.id/index.php/voxpop/arti cle/view/16

16 Sugiyono, Metode Penelitian Kuantitatif, Kualitatif, dan R\&D., (Bandung: CV.Alfabeta, 2015), 15.

17 Rosady Ruslan, Metode Penelitian Public Relations Dan Komunikasi Cet. 5, (Jakarta: Rajawali Pers, 2010), 21.

18 Zainal Abidin Achmad dan Rachmah Ida, Etnografi Virtual Sebagai Teknik Pengumpulan Data dan Metode Penelitian. The Journal of Society \& Media 2 no. 2 (Oktober, 2018): 135, https://doi.org/10.26740/jsm.v2n2.p130-145 
orang pemilik UMKM yang ada di Kelurahan Sidokumpul sebagai informan.

Selain itu, peneliti juga mengumpulkan data melalui studi kepustakaan atau sumber tertulis (library research) yang bersumber baik dari buku maupun internet. Studi ini digunakan untuk mendapatkan data-data sekunder dan gambaran konseptual yang mendukung penelitian. Studi kepustakaan juga dilakukan sebagai dasar mengawali penelitian dan penyusunan artikel. Adapun menggunakan teknik analisis dengan menggunakan bantuan analisis SWOT.

\section{Hasil dan Pembahasan}

Berdasarkan hasil wawancara kami dengan pelaku UMKM di Kelurahan Sidokumpul dapat diketahui terdapat 11 UMKM di Kelurahan Sidokumpul tepatnya di Kampung Tangguh Semeru yang akan diteliti dalam penelitian ini.
Informasi mengenai 11 UMKM disajikan dalam tabel berikut:

Tabel 1: Informasi Pemilik 11 UMKM di Kelurahan Sidokumpul

\begin{tabular}{|c|c|c|c|c|}
\hline No. & NAMA & $\begin{array}{l}\text { UMUR } \\
\text { (Tahun) }\end{array}$ & UMKM & $\begin{array}{l}\text { Lama } \\
\text { Usaha } \\
\text { Berdiri }\end{array}$ \\
\hline 1. & Ima Nurjannah & 39 & $\begin{array}{l}\text { Ancha's } \\
\text { Kitchen }\end{array}$ & $\begin{array}{c}4 \\
\text { tahun } \\
\end{array}$ \\
\hline 2. & Sriani & 40 & Dapur Ibu & 4 \\
\hline 3. & Sulistyaningrum & 35 & Sulis Fashion & 10 \\
\hline 4. & Nawati & 32 & Kedai Kepo & 4 \\
\hline 5. & Alimah & 43 & Donat $\mathrm{Bu} \mathrm{Lim}$ & 5 \\
\hline 6. & $\begin{array}{l}\text { Mariatul } \\
\text { Kiptiyah }\end{array}$ & 24 & Mbak Iyah & 2 \\
\hline 7. & Yudi & 37 & Pak Yudi & 5 \\
\hline 8. & Alfin & 47 & $\begin{array}{c}\text { Kedai Warung } \\
\text { Bu Alfin }\end{array}$ & 7 \\
\hline 9. & Mak Yo & 48 & Mak Yo & 10 \\
\hline 10. & Sri Hartati & 46 & $\begin{array}{c}\text { Makanan } \\
\text { Tradisional } \\
\text { Ibu Tatik }\end{array}$ & 6 \\
\hline 11. & Khusnul & 35 & $\begin{array}{c}\text { Warung Bu } \\
\text { Khusnul }\end{array}$ & 4 \\
\hline
\end{tabular}

Sumber: Data hasil wawancara, 2020

Data hasil wawacara kepada sebelas orang informan, pemilik UMKM telah kami kumpulkan dan rangkum dalam tabel berikut:

Tabel 2: Hasil wawancara sebelas orang informan pemilik UMKM di Kelurahan Sidokumpul

\begin{tabular}{|c|c|c|c|c|c|}
\hline INFORMAN & $\begin{array}{l}\text { DAMPAK } \\
\text { PANDEMI } \\
\text { COVID-19 } \\
\text { TERHADAP } \\
\text { USAHA } \\
\end{array}$ & $\begin{array}{c}\text { MEDIA } \\
\text { SOSIAL YANG } \\
\text { DIGUNAKAN }\end{array}$ & $\begin{array}{c}\text { PROMOSI } \\
\text { YANG TELAH } \\
\text { DILAKUKAN }\end{array}$ & $\begin{array}{c}\text { PENJUALAN } \\
\text { SETELAH } \\
\text { MELALUI } \\
\text { MEDIA SOSIAL }\end{array}$ & $\begin{array}{c}\text { PENDAPAT } \\
\text { MENGENAI } \\
\text { PEMASARAN } \\
\text { MELALUI MEDIA } \\
\text { SOSIAL }\end{array}$ \\
\hline Ima Nurjannah & $\begin{array}{l}\text { Mengalami } \\
\text { penurunan }\end{array}$ & $\begin{array}{l}\text { Media Sosial } \\
\text { Facebook dan } \\
\text { Instagram }\end{array}$ & $\begin{array}{l}\text { Promosi melalui } \\
\text { WA dan dari } \\
\text { orang ke orang }\end{array}$ & $\begin{array}{l}\text { Belum ada } \\
\text { peningkatan }\end{array}$ & $\begin{array}{l}\text { Membantu pelaku } \\
\text { UMKM dalam } \\
\text { menyebarluaskan } \\
\text { informasi produk } \\
\text { umkm }\end{array}$ \\
\hline Sriani & $\begin{array}{l}\text { Mengalami } \\
\text { penurunan }\end{array}$ & $\begin{array}{l}\text { Media Sosial } \\
\text { Facebook }\end{array}$ & $\begin{array}{l}\text { Promosi melalui } \\
\text { WA dan dari } \\
\text { orang ke orang }\end{array}$ & $\begin{array}{l}\text { Belum ada } \\
\text { peningkatan }\end{array}$ & $\begin{array}{l}\text { Sangat membantu } \\
\text { pengetahuan pelaku } \\
\text { UMKM }\end{array}$ \\
\hline Sulistyaningrum & $\begin{array}{l}\text { Mengalami } \\
\text { penurunan }\end{array}$ & $\begin{array}{l}\text { Media Sosial } \\
\text { Facebook dan } \\
\text { Instagram }\end{array}$ & $\begin{array}{l}\text { Promosi dari } \\
\text { orang ke orang }\end{array}$ & $\begin{array}{l}\text { Belum ada } \\
\text { peningkatan }\end{array}$ & $\begin{array}{l}\text { Sangat membantu } \\
\text { menyebarluaskan } \\
\text { informasi usaha kami }\end{array}$ \\
\hline Nawati & $\begin{array}{l}\text { Mengalami } \\
\text { penurunan }\end{array}$ & $\begin{array}{l}\text { Media Sosial } \\
\text { Facebook }\end{array}$ & $\begin{array}{l}\text { Promosi WA dan } \\
\text { dari orang ke } \\
\text { orang }\end{array}$ & $\begin{array}{l}\text { Meningkat namun } \\
\text { belum signifikan }\end{array}$ & $\begin{array}{l}\text { Membantu memberi } \\
\text { informasi ke } \\
\text { masyarakat gresik }\end{array}$ \\
\hline
\end{tabular}




\begin{tabular}{|c|c|c|c|c|c|}
\hline INFORMAN & $\begin{array}{l}\text { DAMPAK } \\
\text { PANDEMI } \\
\text { COVID-19 } \\
\text { TERHADAP } \\
\text { USAHA }\end{array}$ & $\begin{array}{c}\text { MEDIA } \\
\text { SOSIAL YANG } \\
\text { DIGUNAKAN }\end{array}$ & $\begin{array}{c}\text { PROMOSI } \\
\text { YANG TELAH } \\
\text { DILAKUKAN }\end{array}$ & $\begin{array}{c}\text { PENJUALAN } \\
\text { SETELAH } \\
\text { MELALUI } \\
\text { MEDIA SOSIAL }\end{array}$ & $\begin{array}{c}\text { PENDAPAT } \\
\text { MENGENAI } \\
\text { PEMASARAN } \\
\text { MELALUI MEDIA } \\
\text { SOSIAL }\end{array}$ \\
\hline Alimah & $\begin{array}{l}\text { Mengalami } \\
\text { penurunan }\end{array}$ & $\begin{array}{l}\text { Media Sosial } \\
\text { Facebook }\end{array}$ & $\begin{array}{l}\text { Promosi dari } \\
\text { orang ke orang }\end{array}$ & $\begin{array}{l}\text { Meningkat namun } \\
\text { belum signifikan }\end{array}$ & $\begin{array}{l}\text { Membantu } \\
\text { menyebarluaskan } \\
\text { informasi terkait } \\
\text { produk umkm kami }\end{array}$ \\
\hline $\begin{array}{l}\text { Mariatul } \\
\text { Kiptiyah }\end{array}$ & $\begin{array}{l}\text { Mengalami } \\
\text { penurunan }\end{array}$ & $\begin{array}{l}\text { Media } \\
\text { Instagram dan } \\
\text { Facebook }\end{array}$ & $\begin{array}{l}\text { Promosi WA, } \\
\text { Facebook, dan } \\
\text { dari orang ke } \\
\text { orang }\end{array}$ & $\begin{array}{l}\text { Meningkat namun } \\
\text { belum signifikan }\end{array}$ & $\begin{array}{l}\text { Sedikit banyak sudah } \\
\text { membantu } \\
\text { meningkatkan } \\
\text { penjualan produk }\end{array}$ \\
\hline Yudi & $\begin{array}{l}\text { Belum mengalami } \\
\text { penurunan yang } \\
\text { signifikan }\end{array}$ & $\begin{array}{l}\text { Media Sosial } \\
\text { Facebook }\end{array}$ & $\begin{array}{l}\text { Promosi dari } \\
\text { orang ke orang }\end{array}$ & $\begin{array}{l}\text { Meningkat namun } \\
\text { belum signifikan }\end{array}$ & $\begin{array}{l}\text { Membantu kenaikan } \\
\text { penjualan produk }\end{array}$ \\
\hline Alfin & $\begin{array}{l}\text { Mengalami } \\
\text { penurunan }\end{array}$ & Tidak ada & $\begin{array}{l}\text { Promosi dari } \\
\text { orang ke orang }\end{array}$ & Mulai meningkat & $\begin{array}{l}\text { Sangat membantu } \\
\text { mempromosikan } \\
\text { produk kami dengan } \\
\text { memberikan } \\
\text { informasi kepada } \\
\text { masyarakat sekitar }\end{array}$ \\
\hline Mak Yo & $\begin{array}{l}\text { Belum mengalami } \\
\text { penurunan yang } \\
\text { signifikan }\end{array}$ & Tidak ada & $\begin{array}{l}\text { Promosi dari } \\
\text { orang ke orang }\end{array}$ & Mulai meningkat & $\begin{array}{l}\text { Membantu } \\
\text { memberikan } \\
\text { informasi kepada } \\
\text { masyarakat sekitar }\end{array}$ \\
\hline Sri Hartati & $\begin{array}{l}\text { Mengalami } \\
\text { penurunan }\end{array}$ & Tidak ada & $\begin{array}{l}\text { Promosi dari } \\
\text { orang ke orang }\end{array}$ & $\begin{array}{l}\text { Belum ada } \\
\text { peningkatan }\end{array}$ & $\begin{array}{l}\text { Membantu } \\
\text { mempromosikan agar } \\
\text { penjualan kami } \\
\text { meningkat }\end{array}$ \\
\hline Khusnul & $\begin{array}{l}\text { Mengalami } \\
\text { penurunan }\end{array}$ & $\begin{array}{l}\text { Media Sosial } \\
\text { Facebook }\end{array}$ & $\begin{array}{l}\text { Promosi dari } \\
\text { orang ke orang }\end{array}$ & $\begin{array}{l}\text { Meningkat namun } \\
\text { belum signifikan }\end{array}$ & $\begin{array}{l}\text { Sedikit banyak sudah } \\
\text { membantu } \\
\text { mempromosikan dan } \\
\text { meningkatkan } \\
\text { penjualan produk }\end{array}$ \\
\hline
\end{tabular}

Sumber: Data Primer yang diolah, 2020

Informasi dari hasil wawancara diatas dapat diketahui bahwa pelaku UMKM di Kelurahan Sidokumpul rata-rata dijalankan oleh ibu-ibu rumah tangga yang telah menjalankan UMKM nya selama lebih dari 2 . Dan permasalahan utama pelaku UMKM di Kelurahan Sidokumpul dalam masa pandemi COVID-19 saat ini semua pelaku UMKM tengah terkena dampak ekonomi yakni mengalami penurunan dalam penjualan maupun permintaan produk barang atau jasa dari konsumen. Promosi yang dilakukan 11 UMKM di
Kelurahan Sidokumpul saat ini rata-rata masih melalui promosi dari orang ke orang secara langsung dan melalui broadcast Whatsapp, namun ada juga 1 UMKM yang telah meggunakan Facebook. Promosi melalui media sosial masih kurang dilakukan dikarenakan adanya hambatan dalam pengetahuan mengelola media sosial yang kurang dan tidak adanya fasilitas mengakses media sosial. Dengan demikian, tentunya inovasi yang tepat sangatlah diperlukan dalam meningkatkan maupun bangkit dari adanya penurunan 
penjualan produk. Salah satu strategi dalam pemasaran produk yang dilakukan dalam masa pandemi saat ini adalah dengan memanfaatkan media sosial sehingga jangkauan promosi produk atau jasa menjadi lebih luas. Di masa pandemi COVID-19 seperti saat ini, media sosial adalah platform yang paling banyak diakses oleh semua orang. Selain itu, dalam pengaksesan media sosial dapat dengan mudah dilakukan oleh semua kalangan dari kalangan tua hingga kalangan muda. Sehingga, dengan melakukan promosi yang lebih kiat lagi di media sosial tentunya dapat meningkatkan pemasaran walaupun hasil promosi penjualan yang dilakukan belum meningkat secara signifikan mengingat jangka waktu pengaplikasian yang masih terbilang pendek.

\section{PENGGUNA MEDIA SOSIAL}

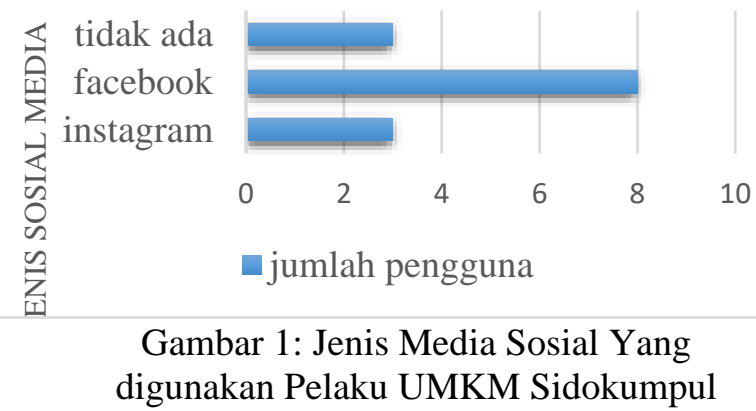

Para pelaku UMKM sidokumpul cukup beragam dalam menggunakan media sosial, seperti halnya facebook dan Instagram. Jika dilihat pada grafik tersebut, para pelaku UMKM Kelurahan Sidokumpul lebih sering menggunakan facebook karena dirasa mudah untuk sebagian pelaku UMKM Kelurahan Sidokumpul. Selain itu, ada pula yang belum menggunakan social media dikarenakan adanya kendala seperti tidak mempunyai handphone android yang memadai dan karena kendala usia sehingga kurang paham dalam menggunakan media sosial.

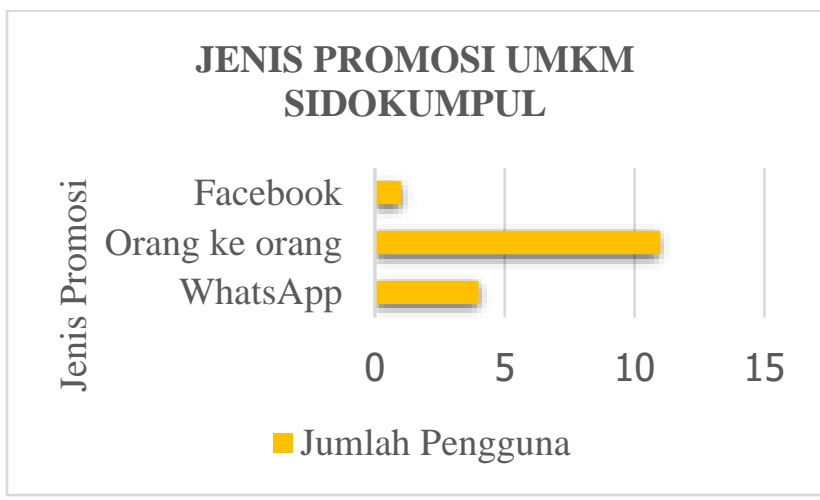

Gambar 2: Jenis Promosi yang Digunakan Pelaku UMKM Sidokumpul

Berdasarkan grafik tersebut, secara keseluruhan pelaku UMKM Kelurahan Sidokumpul mempromosikan barang atau jasa hasil jualannya dengan menawarkan secara langsung ke orangnya karena cara tersebut dirasa mudah, murah dan baik produsen maupun konsumen dapat secara langsung melihat produk yang dijual sehingga dapat menimbulkan kepercayaan diantara keduanya dibandingkan dengan menggunakan social media yang sebelumnya kita belum tahu produk aslinya seperti apa. Selain itu, ada juga pelaku UMKM Kelurahan Sidokumpul yang menggunakan aplikasi WhatsApp dan Facebook untuk melakukan promosi. Namun, ketika adanya pandemi COVID19 yang terjadi pada saat ini membuat cara promosi pelaku UMKM berubah, cara promosi dari orang ke orang dirasa tidak efektif lagi dikarenakan adanya kebijakan jaga jarak fisik yang bertujuan untuk meminimalisir adanya penyebaran COVID-19 yang makin meluas. Sehingga 
banyak masyarakat beralih menggunakan platform media sosial dalam mencari informasi barang atau jasa yang ditawarkan yang di rasa lebih aman.

Pengaruh Promosi Produk Melalui Sosial Media

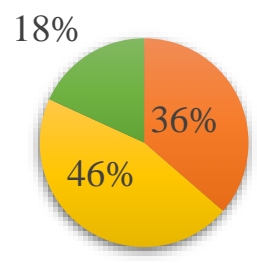

匹 belum meningkat

meningkat namun belum signifikan

- mulai meningkat

Gambar 3: Pengaruh Promosi Produk Melalui Sosial Media

Semenjak adanya pandemi COVID19, semua orang dituntut untuk melakukan adanya jaga jarak fisik (physical distancing) sehingga tidak memungkinkan bagi para pelaku UMKM Kelurahan Sidokumpul untuk melakukan cara promosi produk melalui orang ke orang secara langsung. Maka dari itu, perlu adanya strategi pemasaran yang baru agar usaha yang dijalani bisa bertahan di masa pandemi COVID-19. Beragam platform telah banyak disediakan, seperti facebook, twitter, Instagram dan lain sebagainya. Oleh karena itu, Tim KKN Reguler COVID-19 Kelompok 45 UPN "Veteran" Jawa Timur memberikan alternatif bagi para pelaku UMKM Kelurahan Sidokumpul yaitu dengan mewadahi usaha mereka dalam bentuk promosi online melalui facebook dan Instagram yang notabene nya memiliki peminat mulai dari kalangan muda hingga kalangan tua yang banyak sehingga dirasa lebih efektif dalam menarik minat konsumen dan terbentuklah akun "UMKM Sidokumpul". Akun Facebook dan Instagram tersebut berjalan selama 2 minggu. Selama 2 minggu tersebut, akun Facebook dan Instagram kami kelola dengan semenarik mungkin agar mendapat antusias dari konsumen. Dalam kurun waktu tersebut diperoleh data tentang adanya pengaruh promosi produk melalui sosial media terhadap peningkatan penjualan ketika pandemic COVID-19. Berdasarkan data tersebut menyatakan bahwa sebanyak $36 \%$ belum terlihat adanya peningkatan penjualan, $46 \%$ meningkat namun belum signifikan dan $18 \%$ terlihat mulai meningkat. Hal tersebut bisa terjadi karena waktu yang digunakan terlalu singkat untuk mengetahui adanya efektif atau tidaknya social media terhadap peningkatan penjualan.

Berdasarkan analisis SWOT, diperoleh gambaran sebagai berikut: Strategi (SO): adalah mempertahankan keunggulan produknya sehingga produk tersebut tetap sesuai dengan permintaan dan harapan dari konsumen ketika dipasarkan serta menciptakan produk yang memiliki mutu yang lebih baik kepada sesama kerabat terdekat untuk menunjang kepercayaan konsumen kedepannya.

Strategi (WO): adalah memanfaatkan berbagai jenis media sosial yang mampu membantu penyebaran promosi produk menjadi lebih efektif dan luas serta merekrut pegawai bantuan yang berasal dari kerabat terdekat yang mampu dan mengerti mengenai pengolahan system promosi dan komunikasi konsumen.

Strategi (ST): adalah maksimalkan pengetahuan mengenai keberagaman berdasarkan kategori produknya guna menarik konsumen menggunakan produknya ketika mendapat informasi 
promosi. Serta memanfaatkan SDM produksi yang efektif guna tetap menghasilkan produk yang baik dan dapat dijangkau oleh masyarakat luas.

Strategi (WT): adalah menggunakan desain promosi yang menarik konsumen serta memperluas jangkauan konsumen yang lebih luas.

Berdasarkan analisa SWOT tersebut maka dapat disimpulkan bahwa peluang penggunaan sosial media terhadap penjualan produk UMKM dapat berpengaruh apabila dilakukan secara optimal dari segi lamanya waktu promosi dan adanya pengembangan dalam strategi pemasaran seperti halnya meningkatkan kreatifitas produk sehingga semakin beragam produk yang bisa dijual, mengoptimalisasi sosial media yang ada untuk menambah jaringan relasi pemasaran serta mengalokasikan dana untuk meningkatkan teknologi informasi sehingga mempermudah pemasaran produk, contohnya memasang iklan digital berbayar pada sosial media yang dapat memperluas pangsa pasar. Adapun iklan digital lebih efektif dan murah dibandingkan iklan tradisional seperti sales, brosur, atau katalog yang dapat memakan biaya lebih besar.

Dimasa Pandemi COVID-19 saat ini penting gunanya menerapkan protokol kesehatan guna menjaga peningkatan penyebaran virus Corona tersebut. Sosial media menjadi salah satu sarana yang efektif untuk tetap menjalankan usahanya namun dengan mematuhi aturan protokol kesehatan yang diberlakukan oleh pemerintah.

Tabel 3: Rekapitulasi hasil Analisis SWOT

\begin{tabular}{|c|c|c|}
\hline Eksternal & $\begin{array}{c}\text { Opportunities (Kesempatan) } \\
\text { O }\end{array}$ & $\begin{array}{c}\text { Threats (Ancaman) } \\
\mathrm{T}\end{array}$ \\
\hline \multirow[b]{2}{*}{$\begin{array}{l}\text { Strength } \\
\text { (Kekuatan) } \\
\text { S }\end{array}$} & $\mathrm{SO}$ & ST \\
\hline & $\begin{array}{l}\text { Produk buatan yang masih } \\
\text { dibutuhkan dan diterima } \\
\text { konsumen. } \\
\text { Banyaknya rekomendasi yang } \\
\text { baik dari warga setempat akan } \\
\text { hasil produksi UMKM } \\
\text { tersebut. }\end{array}$ & $\begin{array}{l}\text { Dapat menerima permintaan } \\
\text { konsumen sesuai keinginan } \\
\text { berdasarkan kategori produk yang } \\
\text { ditawarkan. } \\
\text { Produk dapat dikerjakan oleh } \\
\text { UMKM dalam waktu yang relatif } \\
\text { singkat. }\end{array}$ \\
\hline \multirow[b]{2}{*}{$\begin{array}{c}\text { Weakness } \\
\text { (Kelemahan) } \\
\text { W }\end{array}$} & WO & WT \\
\hline & $\begin{array}{l}\text { Mengoptimalkan sosial media } \\
\text { Menggunakan tenaga ahli } \\
\text { yang mampu mengoperasikan } \\
\text { sosial media promosi. }\end{array}$ & $\begin{array}{l}\text { Meningkatkan sistem promosi yang } \\
\text { efektif dan menarik }\end{array}$ \\
\hline
\end{tabular}




\section{Kesimpulan}

Berdasarkan hasil dan pembahasan, penelitian ini menghasilkan dua simpulan. Pertama, platform media sosial berperan penting dalam memasarkan produk UMKM Kelurahan Sidokumpul di masa pandemi COVID-19. Kedua, Pelaku UMKM Kelurahan Sidokumpul belum mengoptimalkan pemasaran produk UMKM melalui media sosial. Beberapa pelaku UMKM sudah menggunakan media sosial untuk pemasaran namun masih dalam skala yang kecil dan belum terorganisir dengan baik. Ketiga, ujicoba optimalisasi pemanfaatan sosial media sebagai sarana pemasaran produk yang baik bagi pelaku UMKM di Kelurahan Sidokumpul dapat menaikkan kembali angka penjualan produk UMKM, dan menjangkau konsumen dengan skala se Kabupaten Gresik dan luar wilayah kabupaten Gresik. Keempat, pemanfaatan sosial media sebagai sarana penunjang yang efektif bagi berjalanya UMKM di masa pandemi COVID-19 sebab pelaku UMKM di Kelurahan Sidokumpul masih dapat menjalankan kegiatan usahanya dengan tetap mematuhi dan melaksanakan protokol kesehatan.

Hasil penelitian ini menyarankan agar para pelaku UMKM penting memahami dan menambah wawasan tentang pentingnya strategi pemasaran digital untuk menunjang keberlangsungan usaha UMKM. Pemasaran digital merupakan peluang yang dapat dikembangkan untuk meraih keuntungan usaha secara maksimal dimasa pandemi COVID-19.

\section{Daftar Pustaka}

Abidin, Zainal Achmad dan Rachmah Ida. Etnografi Virtual Sebagai Teknik Pengumpulan Data dan Metode Penelitian. The Journal of Society \& Media 2 no. 2 (Oktober, 2018): 130145.

https://doi.org/10.26740/jsm.v2n2.p1 $30-145$

Abidin, Zainal Achmad dan Setiyanti O. W. The Effectiveness of Use of Soundcloud Application for Promoting Pop Punk Songs and Music. Bali International Seminar on Science and Technology. Desember 7, 2012.

www.engadget.com/2012/12/07/edito rial-

Abidin, Zainal Achmad, Integrasi Program Dakwah dan Budaya: Studi Etnografi Virtual Mediamorfosis Radio Nada FM Sumenep Madura. Jurnal Komunikasi Islam 09 no 2, (Desember 2019): 238-263. https://doi.org/10.15642/jki.2019.9.2. 239-263.

Aditya, Okto Suryawirawan, Perceived Ease of Usedan Perceived Usefulnessterhadap E-Commerce Intentionmelalui Aplikasi Online Shoppada Mahasiswa di Surabaya. Jurnal MEBIS 4 no 1, (July, 2019): pp 1-8.

https://doi.org/10.33005/mebis.v4i1.4 6

Ardiyanto, Arif . Analisis Penggunaan Media Sosial dalam Pengembangan Usaha Mikro, Kecil, dan Menengah 
(UMKM) di Desa Kemasan Kecamatan Sawit Kabupaten Boyolali. Skripsi, (Surakarta: Fakultas Ekonomi dan Bisnis Islam, Manajemen Bisnis Syariah, Institut Agama Islam Negeri Surakarta, 2018).

Baril, Izzati Haq, Henna Sebagai Komunikasi Identitas Budaya (Studi Fenomenologi Pemah5aman \& Pemaknaan Laki-Laki Pengguna Henna Di Kampung Arab Surabaya). Jurnal Voxpop, 1 no. 1 (September, 2019). 98-107. http://voxpop.upnjatim.ac.id/index.p hp/voxpop/article/view/16

Helmalia dan Afrinawati. "Pengaruh ECommerce Terhadap Peningkatan Usaha Mikro Kecil Dan Menengah Di Kota Padang." Jurnal Ekonomi Dan Bisnis Islam 3 no 2 (Juli 2018): (237246)

DOI: http://dx.doi.org/10.15548/jebi. v3i2.182

Ira, Nur dkk. "Workshop Pemasaran Online Mahasiswa KKN-PPM Universitas PGRI Adi Buana Surabaya Desa Bulang Prambon Sidoarjo", (Surabaya: Abadimas Adi Buana, 2017).

Kaplan, Andres and Michael Haenlein. User Of The World, Unite! The Challenges and Opportunities of Social Media. Business Horizons 53 (Februari, 2010): (59-68). DOI: 10.1016/j.bushor.2009.09.003 Munajat, Enjat dkk. Analisis Penggunaan Media Sosial untuk Mendukung
Pemasaran Produk UMKM (Studi Kasus Kabupaten Subang, Jawa Barat). Jurnal Pengabdian Kepada Masyarakat 2 no 10 (Oktober, 2018): 896-899.

http://jurnal.unpad.ac.id/pkm/article/v iew/20445

Rining, Ertien Nawangsari dan Arimurti Kriswibowo, ed. Potret Masyarakat dan Kebijakan Pemerintah dalam Menghadapi Tantangan Pandemi COVID-19. (Surabaya: Program Studi Ilmu Administrasi Negara, UPN 'Veteran' Jawa Timur, 2020).Ruslan, Rosady Metode Penelitian Public Relations Dan Komunikasi, cet. 5 Jakarta: Rajawali Pers, 2010.

Situmorang, Anggun P. "Sri Mulyani: Corona Beri 3 Dampak Besar Ekonomi Indonesia", Liputan6.com, Juni $30,2020$. https://m.liputan6.com/bisnis/read/42 92763/sri-mulyani-corona-beri-3dampak-besar-ke-ekonomi-indonesia.

Sugiyono, Metode Penelitian Kuantitatif, Kualitatif, dan $R \& D$. Bandung: CV.Alfabeta, 2015.

Swastha, Basu Dharmmesta, Manajemen Penjualan, cet. 5. Yogyakarta: Penerbit BFSE, 2001.

Tutiasri, et al., Creative Marketing Strategies of Sembung Batik. Proceedings of the 2nd International Media Conference 2019 (IMC 2019). (March, 2020): https://doi.org/10.2991/assehr.k.2003 25.030 
Wahyuni, Arum Purbohastuti. "Efektivitas

Media Sosial Sebagai Media Promosi". Jurnal Tirtayasa EKONOMIKA, 12, no. 2 (Oktober 2017): 212-231. jurnal.untirta.ac.id > article > download

Yunita Purnamasari, Ari

Pradhanawati, Wahyu Hidayat,

Analisis peluang E-Commerce Dalam Pengembangan Usaha Mikro Dan Menengah Produk Batik" (Studi Kasus pada Usaha Batik di Semarang), Jurnal Ilmu Administrasi Bisnis 4 no. 4 (September, 2015): 45, https://ejournal3.undip.ac.id/index.php/ jiab/article/view/9226 (42-49. 